\title{
Diagnostic utility of protein excretion in 24-hour urine and the protein to creatinine ratio for adverse perinatal outcomes and time of delivery
}

\author{
İbrahim Ömeroğlu ${ }^{1}$ (D), Didem Dereli Akdeniz ${ }^{2}$ (D), Hakan Gölbaşı ${ }^{1}$ (D), \\ Ceren Gölbaşı ${ }^{3}$ (iD), Atalay Ekin ${ }^{1}$ \\ ${ }^{1}$ Division of Perinatology, Department of Obstetrics and Gynecology, Tepecik Training and Research Hospital, University of Health Sciences, Izmir, Turkey \\ ${ }^{2}$ Department of Endocrinology, Faculty of Medicine, Izmir Economy University, Izmir, Turkey \\ ${ }^{3}$ Department of Obstetrics and Gynecology, Faculty of Medicine, Izmir Tinaztepe University, Izmir, Turkey
}

\begin{abstract}
Objective: Our study aimed to evaluate the perinatal and neonatal outcomes of hypertensive pregnant women with or without proteinuria. We compared the predictivity of spot urinary protein to creatinine $(\mathrm{P} / \mathrm{C})$ ratio and 24-hour protein excretions on outcomes.

Methods: We retrospectively enrolled 230 pregnant women with a new diagnosis of hypertension between 20 and 37 weeks of gestation. We divided the patients into two groups according to the protein level determined by 24-hour urine collection and $\mathrm{P} / \mathrm{C}$ ratio. The presence and level of proteinuria, its relationship with the P/C ratio, and the relationship between these findings and perinatal outcomes were evaluated.

Results: Gestational age at delivery weeks and latency period (duration between diagnosis of hypertension and delivery) were significantly earlier in pregnant women with $\geq 300 \mathrm{mg} / 24-\mathrm{h}$ and $\mathrm{P} / \mathrm{C}$ ratio $\geq 0.3$. Adverse neonatal outcomes were significant in patients with proteinuria $\geq 300 \mathrm{mg} / 24$-hour and $\mathrm{P} / \mathrm{C}$ ratio $\geq 0.3$. Urinary protein levels in 24-hour urine were significantly higher in pregnant women with $\mathrm{P} / \mathrm{C}$ ratio $\geq 0.3$ and a significantly positive correlation was found between 24-h proteinuria and P/C $(r=0.382, \mathrm{p}<0.001)$.

Conclusion: Our study demonstrated that a protein loss of $\geq 300 \mathrm{mg}$ in 24-h and a $\mathrm{P} / \mathrm{C}$ ratio in spot urine $\geq 0.3$ in hypertensive pregnant women is associated with adverse perinatal outcomes. Furthermore, we have identified that proteinuria $\geq 300 \mathrm{mg} /$ day and spot urine $\mathrm{P} / \mathrm{C}$ ratio $\geq 0.3$ in hypertensive pregnant women make them prone to early delivery risk.
\end{abstract}

Keywords: Pregnancy, proteinuria, preeclampsia.
Özet: 24 saatlik idrarda protein atılımının tanılayıcı kullanımı ve advers perinatal sonuçlar ile doğum zamanı için protein-kreatinin oranı

Amaç: Çalışmamızda, proteinürisi olan veya olmayan hipertansif gebelerde perinatal ve neonatal sonuçları değerlendirmeyi amaçladık. Spot üriner protein ile kreatinin oranının (P/C) ve 24-saatlik protein atılımının sonuçlar üzerindeki prediktivitesini karşılaştırdik.

Yöntem: Gebeliğin 20. ve 37. haftaları arasında yeni hipertansiyon tanısı almış 230 gebe retrospektif olarak çalışmaya dahil edildi. Alınan 24 saatlik idrar ve $\mathrm{P} / \mathrm{C}$ ile belirlenen protein seviyesine göre hastalar iki gruba ayrıldı. Proteinüri varlığı ve seviyesi, $\mathrm{P} / \mathrm{C}$ oranıyla olan ilişkisi ve bu bulgular ile perinatal sonuçlar arasındaki ilişki değerlendirildi.

Bulgular: Doğum esnasındaki gestasyonel yaş ve gecikme dönemi (hipertansiyon tanısı ile doğum arasındaki süre), $\geq 300 \mathrm{mg} / 24$ saat ve $\mathrm{P} / \mathrm{C} \geq 0.3$ değerlerine sahip gebelerde anlamlı şekilde daha erkendi. Advers neonatal sonuçlar, proteinürisi $\geq 300 \mathrm{mg} / 24$ saat ve $\mathrm{P} / \mathrm{C} \geq 0.3$ olan hastalarda anlamliydı. 24 saatlik idrarda üriner protein seviyeleri, $\mathrm{P} / \mathrm{C} \geq 0.3$ değerine sahip gebelerde anlamlı şekilde daha yüksekti ve 24 saatlik proteinüri ile $\mathrm{P} / \mathrm{C}$ arasında anlamlı şekilde pozitif bir korelasyon bulundu $(\mathrm{r}=0.382, \mathrm{p}<0.001)$.

Sonuç: Çalışmamız, hipertansif gebelerde 24 saatte $\geq 300 \mathrm{mg}$ 'lik bir protein kaybı ve spot idrarda $\geq 0.3^{\prime}$ lük bir P/C oranının advers perinatal sonuçlarla ilişkili olduğunu ortaya koymuştur. Ayrıca, hipertansif gebelerde $\geq 300 \mathrm{mg} /$ gün seviyesinde proteinürinin ve $\geq 0.3$ 'lük spot idrar $\mathrm{P} / \mathrm{C}$ oranının bu gebeleri erken doğum riskine eğilimli kıldığını tespit ettik.

Anahtar sözcükler: Gebelik, proteinüri, preeklampsi.

Correspondence: İbrahim Ömeroğlu MD. Division of Perinatology, Department of Obstetrics and Gynecology, Tepecik Training and Research Hospital, University of Health Sciences, İzmir, Turkey. e-mail: dribrahimomeroglu@gmail.com / Received: November 22, 2021; Accepted: December 3, 2021 How to cite this article: Ömeroğlu İ, Dereli Akdeniz D, Gölbaşı H, Gölbaşı C, Ekin A. Diagnostic utility of protein excretion in 24-hour urine and the protein to creatinine ratio for adverse perinatal outcomes and time of delivery. Perinatal Journal 2021;29(3):255-265. doi:10.2399/prn.21.0293015 


\section{Introduction}

Hypertension complicates nearly $10 \%$ of pregnancies worldwide. Chronic hypertension, gestational hypertension, preeclampsia/eclampsia, and superimposition of preeclampsia on chronic hypertension are all accepted hypertensive disorders associated with pregnancy. ${ }^{[1]}$

Clinicians routinely perform a urinalysis for proteinuria in their clinical practice and it helps to predict pregnancy complications. Elevated protein concentration in twenty-four-hour urine was accepted as a diagnostic criterion for preeclampsia for many years, but renal problems can also cause these elevations. The high protein concentrations in urine may be the result of a high plasma protein concentration, increases in glomerular permeability, decreases of tubular protein reabsorption, and alterations of renal hemodynamics. ${ }^{[2]}$ For the diagnosis of preeclampsia, proteinuria is accepted sufficient but it is not necessary since 2013. However, the importance of protein excretions as a predictive factor for risk assessment is still controversial, especially in women with hypertensive problems. ${ }^{[3]}$

The increase in urinary protein excretion during the pregnancy period is accepted as normal. The causes of this change are hypervolemia-associated hemodilution and renal blood flow increase. During the third trimester, healthy pregnant women can have protein in their urine up to 200 to $260 \mathrm{mg}$ per day. ${ }^{[4,5]}$ The method that is accepted as a "gold standard" in proteinuria assessment is calculating the protein concentration in urine collected for 24 hours (24-h). There must be at least 0.3 $g$ protein in twenty-four-hour urine for the definition of proteinuria during pregnancy. ${ }^{[3]}$ However, it is really hard to collect a twenty-four-hour urine sample for anyone and this may cause errors even before delivering the sample to the laboratory. All these reasons can result in mistakes in the results or some alterations in the application of the assay. ${ }^{[6]}$ The assessment of protein to creatinine ratio can be a fast and easy option for quantitative evaluation of proteinuria (in this article, $\mathrm{P} / \mathrm{C}$ will be used as the protein to creatinine ratio in a spot urine). It is an easy marker that is found by dividing the protein amount $(\mathrm{mg} / \mathrm{dl})$ to the creatinine amount $(\mathrm{mg} / \mathrm{dl})$ and spot urine can be used for this test. ${ }^{[7]}$ But there is no accepted cut-off value of this ratio and there are a lot of investigations going on for the determination of that cut-off value. ${ }^{[8]}$

Our study aimed to find a predictive marker for maternal and fetal risks in pregnant women with hypertension. For this purpose, we investigated $24-\mathrm{h}$ protein- uria, and tried to redefine its importance in the diagnosis of preeclampsia. We also tried to find a proper cut-off value for the $\mathrm{P} / \mathrm{C}$ ratio to make it easy to use urinary protein excretion as a marker. Another goal of our study was to investigate the effect of $24-\mathrm{h}$ proteinuria and $\mathrm{P} / \mathrm{C}$ on the period between the diagnosis of hypertension and the time of delivery (latency period) in hypertensive pregnant women.

\section{Methods}

In this study, we retrospectively enrolled 230 pregnant women with gestational hypertension from the University of Health Sciences Tepecik Training and Research Hospital, Department of Obstetrics and Gynecology between June 2018 and December 2020. The Ethics Committee of the University of Health Sciences approved our study. All data were collected from the digital patient records of our department. Single pregnancies complicated with hypertension between 20 and 37 weeks of gestation were included in our study. Women with chronic essential/secondary hypertension which is diagnosed before pregnancy, women who have systemic illnesses like diabetes mellitus and Hashimoto's disease, and pre-diagnosed renal problems are excluded from our study. Gestational diabetes, pregnant women with often urinary tract infections, multiple pregnancies, premature membrane ruptures were also excluded. Pregnant women who underwent assisted reproductive techniques were not included in our study groups. Patients with thrombocyte count lower than $150,000 / \mu \mathrm{L}$ or elevated liver function tests (two times higher than the normal value) were also excluded. We defined systolic blood pressure (BP) higher than 14 $\mathrm{cmHg}$ and/or diastolic $\mathrm{BP}$ higher than $9 \mathrm{cmHg}$ in a previously normotensive pregnant woman as hypertensive. We divided all patients into two groups according to the level of protein detected by either 24-h urine collection or $\mathrm{P} / \mathrm{C}$. The cut-off value to define proteinuria for $24-\mathrm{h}$ urine collection was $300 \mathrm{mg} / 24-\mathrm{h}$ and for $\mathrm{P} / \mathrm{C}$ was $\geq 0.3$.

During the period of our study, some of pregnant women were hospitalized due to poorly controlled blood pressure or fetal growth restriction. After hospitalization, the pregnant women were evaluated for BP every 4-6 hours. Biochemical analysis, coagulation profiles, creatinine clearance, and urinary protein excretion levels were controlled on admission and then 2 times every week. To monitor the fetus, we performed non-stress tests (NST) daily. The fetal growth was assessed by using sonographic evaluations and the amniotic fluid index was evaluated 
every week. As a first-line antihypertensive drug oral methyldopa or hydralazine was used. If these were insufficient, intravenous (IV) hydralazine or continuous IV nicardipine infusion were the second-line drug choices. Before the 34th week of gestation, if there was an urgent indication for labor within one week, two doses of intramuscular betamethasone injections were used to accelerate fetal lung maturation.

\section{Maternal indications for preterm labor:}

- Despite administration of adequate doses of antihypertensive medications, ongoing high blood pressure,

- Eclampsia and hypertensive encephalopathy risk (visual disturbance and severe headache),

- Hemolysis, elevated liver enzymes, and low platelet count (HELLP),

- Risk of acute renal failure,

- Placental abruption.

\section{Fetal indications for preterm labor:}

- Detection of repeated late decelerations in fetal heart rate or severe variable decelerations in NST,

- Biophysical profile score $\leq 4$,

- Reversed end-diastolic flow in the Doppler USG of the umbilical artery at or after 32 weeks of gestation.

Blood samples were collected after ten hours of overnight fasting in the morning from $8 \mathrm{AM}$ to $9 \mathrm{AM}$. Serum hemoglobin, serum glutamic-oxaloacetic transaminase (SGOT), serum glutamate pyruvate transaminase (SGPT), and gamma-glutamyl transferase (GGT), urea and creatinine levels were measured by Olympus AU 2700 automated analyzer (Olympus Health Systems, Tokyo, Japan). Urine samples were collected in the week of diagnosis of hypertension. The 24-hour urine collection was started in the morning after the overnight urine was disposed of. All urine during day and night including the first urine the next morning was collected. The creatinine and protein values were measured by Jaffe and calorimetric methods. The total urinary protein $(\mathrm{mg})$ was calculated with the formula of total urinary volume $(\mathrm{dl}) \times$ the protein concentration $(\mathrm{mg} / \mathrm{dl})$.

Data were analyzed using IBM SPSS Statistics 21.0 (IBM Corp. Released 2012. IBM SPSS Statistics for Windows, Version 21.0; Armonk, NY, USA). Continuous variables were expressed as mean \pm standard deviation, categorical variables were expressed as numbers and percentages. Shapiro-Wilk test was used for the conformity of data to normal distribution. To compare the mean values between two normally distributed groups, we used independent samples t-test. We used Fisher's exact chi- square tests and Pearson's chi-square to determine the association between two categorical variables. The relationship evaluated by linear $\mathrm{p}<0.05$ was accepted as statistically significant.

\section{Results}

In this study, the results of 230 pregnant women with hypertension were evaluated. Of these, 90 (39.1\%) had 24-hour proteinuria $\geq 300 \mathrm{mg}$, and $140(60.9 \%)$ had 24 hour proteinuria $<300 \mathrm{mg}$. Of 230 pregnant women, 70 (30.4\%) had $\mathrm{P} / \mathrm{C} \geq 0.3$ and $160(69.6 \%)$ had $\mathrm{P} / \mathrm{C}<0.3$. Demographic features and laboratory results of the patients according to $24-\mathrm{h}$ proteinuria are demonstrated in Table 1.

Mean urine volume, urinary protein, and urinary creatinine levels ( $\mathrm{p}<0.001$ for all) were significantly higher in pregnant women with proteinuria $\geq 300 \mathrm{mg} / 24-\mathrm{h}$. P/C ratio was also higher in pregnant women with proteinuria $\geq 300 \mathrm{mg} / 24-\mathrm{h}(0.9 \pm 2.9$ vs $0.2 \pm 0.2 ; \mathrm{p}<0.001)$. There was no significant difference between two groups in terms of the plasma levels of hemoglobin, thrombocyte, ALT, AST, and creatinine.

Perinatal outcomes of pregnant women according to 24-h proteinuria are demonstrated in Table 2 . Gestational age at delivery weeks $(\mathrm{p}<0.001)$ and duration between diagnosis of hypertension and delivery (latency period) $(\mathrm{p}<0.001)$ were significantly earlier in pregnant women with proteinuria $\geq 300 \mathrm{mg} / 24-\mathrm{h}$. The 1 - and 5 minute Apgar scores and birth weights were significantly lower in pregnant women with proteinuria $\geq 300 \mathrm{mg} / 24$ $\mathrm{h}(\mathrm{p}<0.001, \mathrm{p}<0.001$, and $\mathrm{p}=0.001$, respectively). Adverse neonatal outcomes, including admission to the Neonatal Intensive Care Unit (NICU), intubation, respiratory distress syndrome (RDS), and RDS with meconium aspiration were significantly higher in pregnant women with proteinuria $\geq 300 \mathrm{mg} / 24$-hours $(\mathrm{p}<0.001$ for all of the variables).

Demographic features and laboratory results of the pregnant women when they grouped according to P/C ratio are demonstrated in Table 3. Mean urine volume $(\mathrm{p}=0.018)$ and urinary protein $(\mathrm{p}<0.001)$ levels in $24-$ hour urine were significantly higher in pregnant women with $\mathrm{P} / \mathrm{C} \geq 0.3$. The mean $\mathrm{P} / \mathrm{C}$ ratio in spot urine was significantly higher in pregnant women with $\mathrm{P} / \mathrm{C} \geq 0.3$ $(\mathrm{p}<0.001)$. There was no significant difference between the two groups in the plasma levels of hemoglobin, thrombocyte, ALT, AST, and creatinine.

Perinatal outcomes of pregnant women according to $\mathrm{P} / \mathrm{C}$ are demonstrated in Table 4. Gestational age at 
Table 1. Demographic features and laboratory results of the patients according to $24-\mathrm{h}$ urinary protein levels.

\begin{tabular}{|c|c|c|c|c|}
\hline & & $\begin{array}{l}\text { 24-h proteinuria }(\geq 300 \mathrm{mg}) \\
\qquad(\mathrm{n}=90)\end{array}$ & $\begin{array}{l}\text { 24-h proteinuria }(<300 \mathrm{mg}) \\
\qquad(\mathrm{n}=140)\end{array}$ & p-value \\
\hline \multicolumn{2}{|c|}{ Maternal age (years) } & $30.1 \pm 5.9$ & $28.8 \pm 6.1$ & 0.154 \\
\hline \multicolumn{2}{|l|}{ Gravidity } & $2.7 \pm 1.5$ & $2.7 \pm 1.5$ & 0.782 \\
\hline \multicolumn{2}{|l|}{ Parity } & $1.3 \pm 1.1$ & $1.4 \pm 1.2$ & 0.821 \\
\hline \multirow[t]{4}{*}{ 24-h urine } & Volume (ml) & $2286.6 \pm 1131.6$ & $1562.5 \pm 826.8$ & $<0.001$ \\
\hline & Protein (mg) & $733.1 \pm 1380.7$ & $179.6 \pm 59.4$ & $<0.001$ \\
\hline & Urea $(\mathrm{mg} / \mathrm{dl})$ & $13.9 \pm 5.1$ & $14.7 \pm 7.3$ & 0.180 \\
\hline & Creatinine (mg/dl) & $1282.3 \pm 552.9$ & $1010.1 \pm 340.9$ & $<0.001$ \\
\hline \multicolumn{2}{|l|}{ Spot urine P/C } & $0.9 \pm 2.9$ & $0.2 \pm 0.2$ & $<0.001$ \\
\hline \multirow[t]{5}{*}{ Plasma levels } & Hemoglobin (mg/dl) & $11.3 \pm 1.2$ & $11.3 \pm 1.2$ & 0.565 \\
\hline & Platelet (per mm³) & $226,155 \pm 55,625$ & $228,335 \pm 59,867$ & 0.914 \\
\hline & ALT (IU) & $15.9 \pm 6.4$ & $15.85 \pm 4.94$ & 0.836 \\
\hline & AST (IU) & $13.8 \pm 14.1$ & $12.36 \pm 6.41$ & 0.642 \\
\hline & Creatinine (mg/dl) & $0.6 \pm 0.1$ & $0.6 \pm 0.1$ & 0.275 \\
\hline
\end{tabular}

Data are presented as mean \pm standard deviation. ALT: alanine transaminase; AST: aspartate aminotransferase; P/C: protein to creatinine ratio.

Table 2. Perinatal outcomes of patients according to 24-h urinary protein levels.

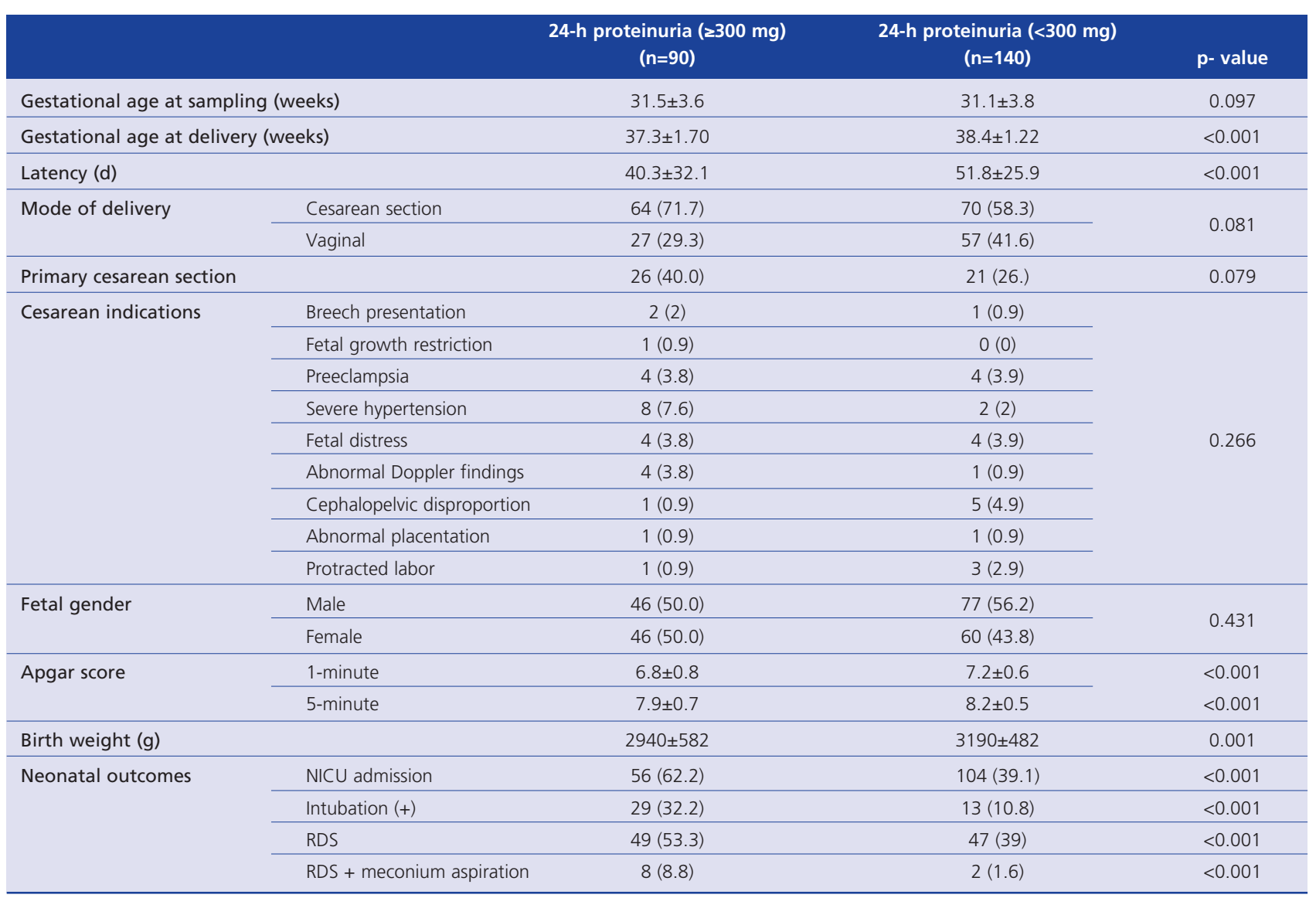

Data are presented as mean \pm standard deviation or $\mathrm{n}(\%)$. NICU: neonatal intensive care unit; RDS: respiratory distress syndrome. 
Diagnostic utility of protein excretion in 24-hour urine and the P/C ratio for adverse perinatal outcomes and time of delivery

Table 3. Demographic features and laboratory results of the patients according to spot urine P/C.

\begin{tabular}{|c|c|c|c|c|}
\hline & & $\begin{array}{l}\text { Spot urine } P / C(\geq 0.3) \\
\qquad(\mathrm{n}=70)\end{array}$ & $\begin{array}{l}\text { Spot urine } P / C(<0.3) \\
\qquad(n=160)\end{array}$ & p-value \\
\hline \multicolumn{2}{|c|}{ Maternal age (years) } & $30.1 \pm 5.81$ & $28.9 \pm 6.12$ & 0.167 \\
\hline \multicolumn{2}{|l|}{ Gravidity } & $2.87 \pm 1.38$ & $2.71 \pm 1.55$ & 0.227 \\
\hline \multicolumn{2}{|l|}{ Parity } & $1.43 \pm 1.06$ & $1.34 \pm 1.16$ & 0.347 \\
\hline \multirow[t]{4}{*}{ 24-h urine } & Volume (ml) & $2100 \pm 1110$ & $1740 \pm 963$ & 0.018 \\
\hline & Protein (mg) & $756 \pm 1340$ & $220 \pm 112$ & $<0.001$ \\
\hline & Urea $(\mathrm{mg} / \mathrm{dl})$ & $14.3 \pm 5.40$ & $14.0 \pm 8.09$ & 0.180 \\
\hline & Creatinine (mg/dl) & $1040 \pm 372$ & $1160 \pm 486$ & 0.121 \\
\hline \multicolumn{2}{|l|}{ Spot urine P/C } & $1.1 \pm 3.3$ & $0.2 \pm 0.1$ & $<0.001$ \\
\hline \multirow[t]{5}{*}{ Plasma levels } & Hemoglobin (mg/dl) & $11.3 \pm 1.2$ & $11.4 \pm 1.2$ & 0.476 \\
\hline & Platelet (per mm³) & $227,000 \pm 53,300$ & $228,000 \pm 59,300$ & 0.801 \\
\hline & ALT (IU) & $14.6 \pm 16.5$ & $12.3 \pm 6.04$ & 0.888 \\
\hline & AST (IU) & $16.4 \pm 6.60$ & $15.7 \pm 5.02$ & 0.618 \\
\hline & Creatinine (mg/dl) & $0.631 \pm 0.127$ & $0.608 \pm 0.120$ & 0.074 \\
\hline
\end{tabular}

Data are presented as mean \pm standard deviation. ALT: alanine transaminase; AST: aspartate aminotransferase; P/C: protein to creatinine ratio.

Table 4. Perinatal outcomes of patients according to spot urine $P / C$.

\begin{tabular}{|c|c|c|c|c|}
\hline & & $\begin{array}{l}\text { Spot urine } P / C(\geq 0.3) \\
\qquad(n=70)\end{array}$ & $\begin{array}{l}\text { Spot urine } P / C(<0.3) \\
\qquad(n=160)\end{array}$ & p-value \\
\hline \multicolumn{2}{|c|}{ Gestational age at sampling (weeks) } & $31.8 \pm 3.8$ & $31.0 \pm 3.9$ & 0.082 \\
\hline \multicolumn{2}{|c|}{ Gestational age at delivery (weeks) } & $37.3 \pm 1.8$ & $38.2 \pm 1.3$ & $<0.001$ \\
\hline \multicolumn{2}{|l|}{ Latency } & $38.2 \pm 28.3$ & $51.0 \pm 28.6$ & $<0.001$ \\
\hline \multirow[t]{2}{*}{ Mode of delivery } & Cesarean section & $52(76.5)$ & $93(57.8)$ & \multirow{2}{*}{0.011} \\
\hline & Vaginal & $16(23.5)$ & $68(42.2)$ & \\
\hline \multicolumn{2}{|l|}{ Primer cesarean section } & $19(36.5)$ & $28(30.1)$ & 0.427 \\
\hline \multirow[t]{9}{*}{ Cesarean section indications } & Breech presentation & $2(1.9)$ & $1(0.98)$ & \multirow{9}{*}{0.624} \\
\hline & Fetal growth restriction & $1(0.95)$ & $0(0.0)$ & \\
\hline & Preeclampsia & $3(2.86)$ & $5(4.9)$ & \\
\hline & Severe hypertension & $5(4.76)$ & $5(4.9)$ & \\
\hline & Fetal distress & $2(1.9)$ & $6(5.88)$ & \\
\hline & Abnormal Doppler findings & $3(2.86)$ & $2(1.96)$ & \\
\hline & Cephalopelvic disproportion & $1(0.95)$ & $5(4.9)$ & \\
\hline & Abnormal placentation & $1(0.95)$ & $1(0.98)$ & \\
\hline & Protracted labor & $1(0.95)$ & $3(2.94)$ & \\
\hline \multirow[t]{2}{*}{ Fetal gender } & Male & $36(52.9)$ & $87(54.0)$ & \multirow{2}{*}{0.994} \\
\hline & Female & $32(47.1)$ & $74(46.0)$ & \\
\hline \multirow[t]{2}{*}{ Apgar score } & 1-minute & $6.8 \pm 0.8$ & $7.2 \pm 0.6$ & $<0.001$ \\
\hline & 5-minute & $7.9 \pm 0.7$ & $8.2 \pm 0.5$ & $<0.001$ \\
\hline \multicolumn{2}{|l|}{ Birth weight (g) } & $2910 \pm 590$ & $3160 \pm 496$ & 0.004 \\
\hline \multirow[t]{4}{*}{ Neonatal outcomes } & NICU admission & $24(35.3)$ & $115(71.4)$ & $<0.001$ \\
\hline & Intubation (+) & $25(36.8)$ & $7(4.3)$ & $<0.001$ \\
\hline & RDS & $36(52.9)$ & $46(28.6)$ & $<0.001$ \\
\hline & RDS + meconium aspiration & $8(11.8)$ & $0(0)$ & $<0.001$ \\
\hline
\end{tabular}

Data are presented as mean \pm standard deviation or $\mathrm{n}(\%)$. NICU: neonatal intensive care unit; RDS: respiratory distress syndrome. 
delivery $(\mathrm{p}<0.001)$ and latency period $(\mathrm{p}<0.001)$ were significantly earlier in patients with $\mathrm{P} / \mathrm{C} \geq 0.3$. Different from pregnant women with proteinuria $\geq 300 \mathrm{mg} / 24-\mathrm{h}$, the rates of cesarean delivery were significantly higher in pregnant women with $\mathrm{P} / \mathrm{C} \geq 0.3$. The 1 -minute $(\mathrm{p}<0.001)$ and 5-minute $(\mathrm{p}<0.001)$ Apgar scores and birth weights $(\mathrm{p}=0.004)$ were significantly lower in pregnant women with $\mathrm{P} / \mathrm{C} \geq 0.3$ compared to those with $\mathrm{P} / \mathrm{C}<0.3$. All adverse neonatal outcomes were significantly higher in pregnant women with $\mathrm{P} / \mathrm{C} \geq 0.3$ ( $\mathrm{p}<0.001$ for all parameters).

Regression analysis was used to identify the strength of relationship between two tests. The latency period and delivery weeks were significantly negatively correlated both with the 24-h urinary protein concentration and $\mathrm{P} / \mathrm{C}$ as shown in Fig. 1 ( $\mathrm{r}=-0.140, \mathrm{p}=0.034$; $\mathrm{r}=-$ 0.423, p $<0.001$, respectively) and Fig. 2 ( $\mathrm{r}=-0.030$, $\mathrm{p}=0.049 ; \mathrm{r}=-0.277, \mathrm{p}<0.001$, respectively).

A comparison of proteinuria with both tests is presented in Table 5. There was a statistically significant association between 24-h proteinuria and P/C. Furthermore, a statistically significant positive correlation was observed between 24-h proteinuria and P/C $(\mathrm{r}=0.382, \mathrm{p}<0.001)($ Fig. 3).

\section{Discussion}

This study indicates that proteinuria in pregnant women with hypertension is an important indicator of adverse perinatal outcomes. The study also displayed an important warning message for preterm delivery in pregnancies complicated by hypertension.

Our study demonstrates that the spot urine $\mathrm{P} / \mathrm{C}$ ratio is as reliable as the $24-\mathrm{h}$ urine test in pregnant women with hypertension, and a spot urine $\mathrm{P} / \mathrm{C}$ ratio cut-off 30 $\mathrm{mg} / \mathrm{mmol}$ matches with proteinuria in the corresponding 24-h urine sample. During pregnancy, 24-h urine collection is the gold standard for the diagnosis of proteinuria. ${ }^{[3]}$ The test itself has some problems, it takes a long time, and can cause some errors even before laboratory evaluation. It is also important to remember that laying in the supine position may cause urine stagnation in the urinary system, and we may not be able to collect actual 24-h urinary volume. ${ }^{[7]}$ Some authorities have suggested that the spot urine $\mathrm{P} / \mathrm{C}$ ratio should be the preferred method in the diagnosis of proteinuria. In a study by Waugh et al., they found that the results of a 24-h urine sample have comparable results to the spot urine sample in the diagnosis of proteinuria in hypertensive pregnancies. ${ }^{[9]}$ Their study results do not support the necessity of a 24-h urine sample collection for hypertensive pregnant women. In clinical practice, once the spot urine $\mathrm{P} / \mathrm{C}$ ratio is confirmed to be $\geq 0.3$, no further proteinuria measurements are needed during the follow-up period in hypertensive pregnancy. A spontaneous negative spot urine $\mathrm{P} / \mathrm{C}$ ratio during the doctor visit may give useful evidence to eliminate the presence of significant proteinuria and also the risk of preeclampsia. ${ }^{[10-12]}$ Our findings support the conclusion of Morikawa et al. They found spot urine $\mathrm{P} / \mathrm{C}$ ratio was a significant marker for prediction of the time of delivery and perinatal outcomes. ${ }^{[13]}$

An interesting finding of our study is the spot urine $\mathrm{P} / \mathrm{C}$ ratio was found to be $>0.3$ in $7.1 \%(10 / 140)$ of patients with proteinuria $<300 \mathrm{mg} / 24-\mathrm{h}$. Among those 10 patients, 1 had thrombocytopenia, 2 had severe hypertension despite intensive antihypertensive treatment, 1 had severe headache resistant to medications and 1 had fetal distress signs. Those 5 pregnancies were delivered before 35 weeks of gestation. Even though the number of 10 is not enough to make an efficient statistical evaluation, it is enough to conclude that the risk is higher in patients with spot urine $\mathrm{P} / \mathrm{C}$ ratio positive and 24-h proteinuria negative. More studies are needed for the determination of the risks of patients whose proteinuria was diagnosed by both tests.

The fetal outcome from uncomplicated pregnancy hypertension gives results similar to normal pregnancies about fetal outcomes. ${ }^{[14]}$ Cruz et al. evaluated that the best time for labor with hypertensive pregnancies without any other complication was between 38 and 39 weeks of gestation. They suggested a labor induction between those weeks may result in the best neonatal and maternal outcomes. ${ }^{[15]}$ Their finding was supported by Yuce et al. ${ }^{[16]}$ Gofton et al. found similar Apgar scores in hypertensive pregnant women and their control group ${ }^{[17]}$ Ono et al. studied 120 essential hypertensive pregnant women ${ }^{[18]}$ In their study, the pregnancy outcomes in women with essential hypertension were better than those in women who have preeclampsia superimposed chronic hypertension.

With this investigation, we found an important result. The neonatal outcomes in the detailed analysis showed us that hypertensive pregnant women with proteinuria $\geq 300 \mathrm{mg} / 24-\mathrm{h}$ and spot urine $\mathrm{P} / \mathrm{C}$ ratio $\geq 0.3$ gave birth to infants with more complications. The 
a

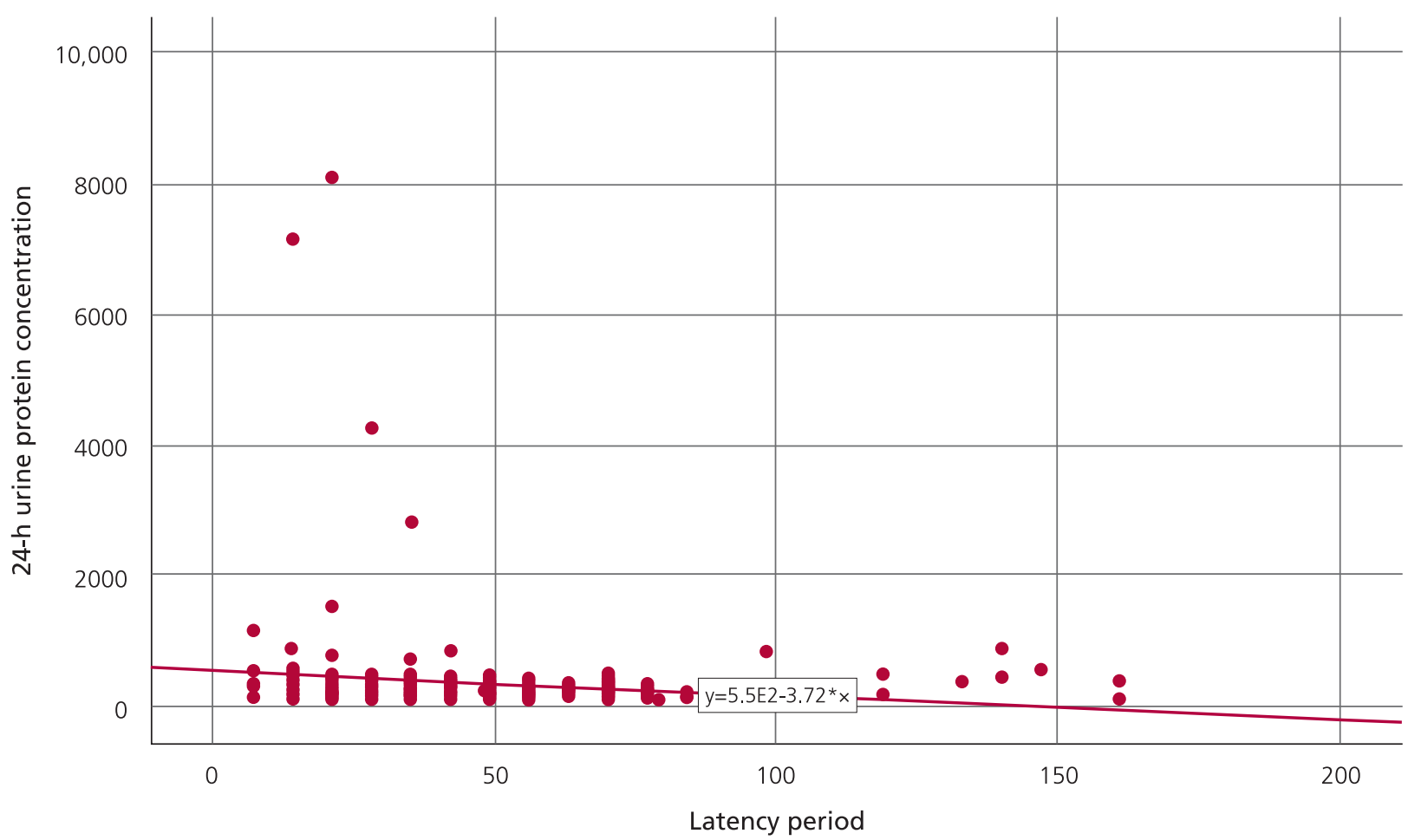

b

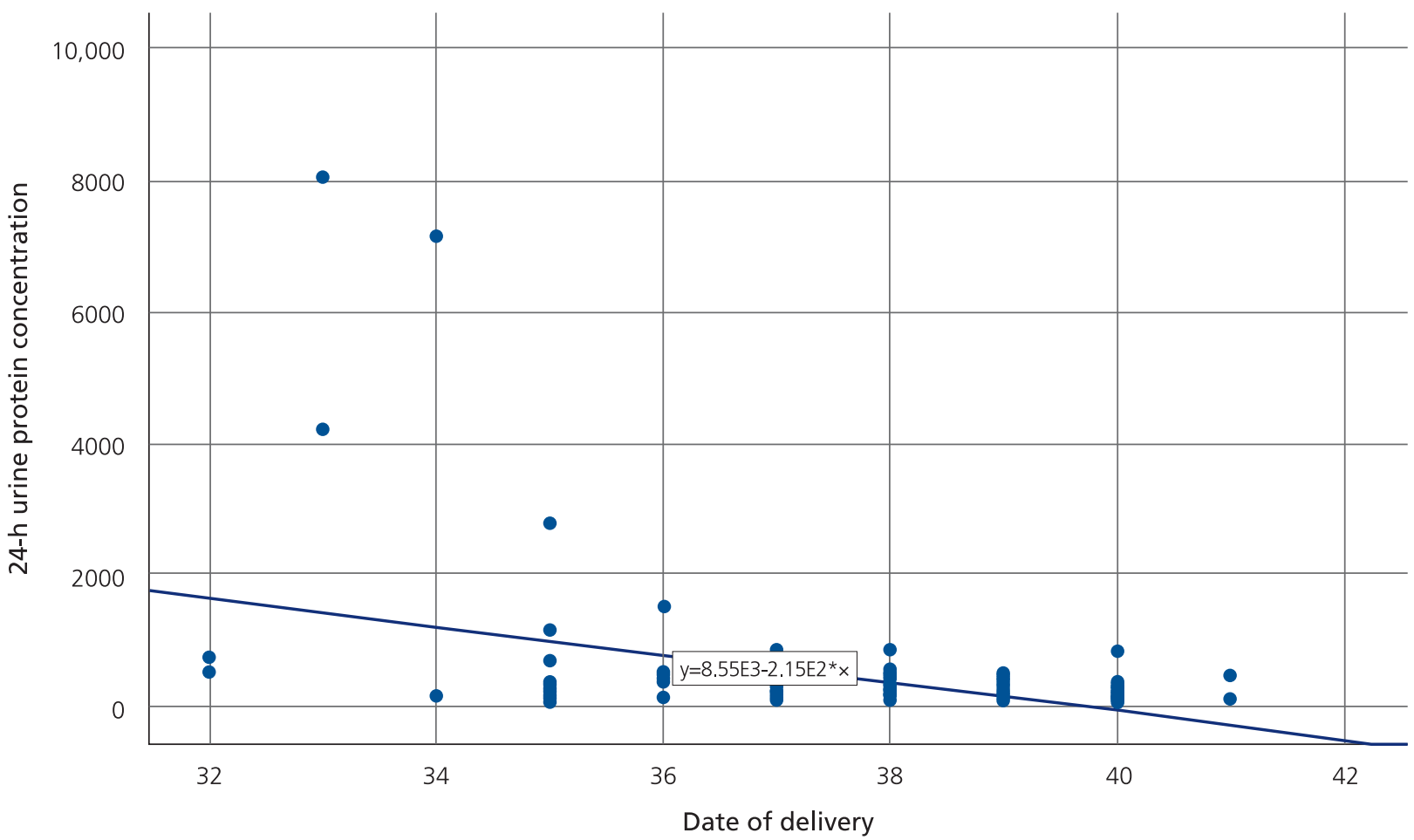

Fig. 1. (a) Correlation between 24-h urinary protein concentration and latency period. (b) Correlation between 24-h urinary protein concentration and date of delivery. 


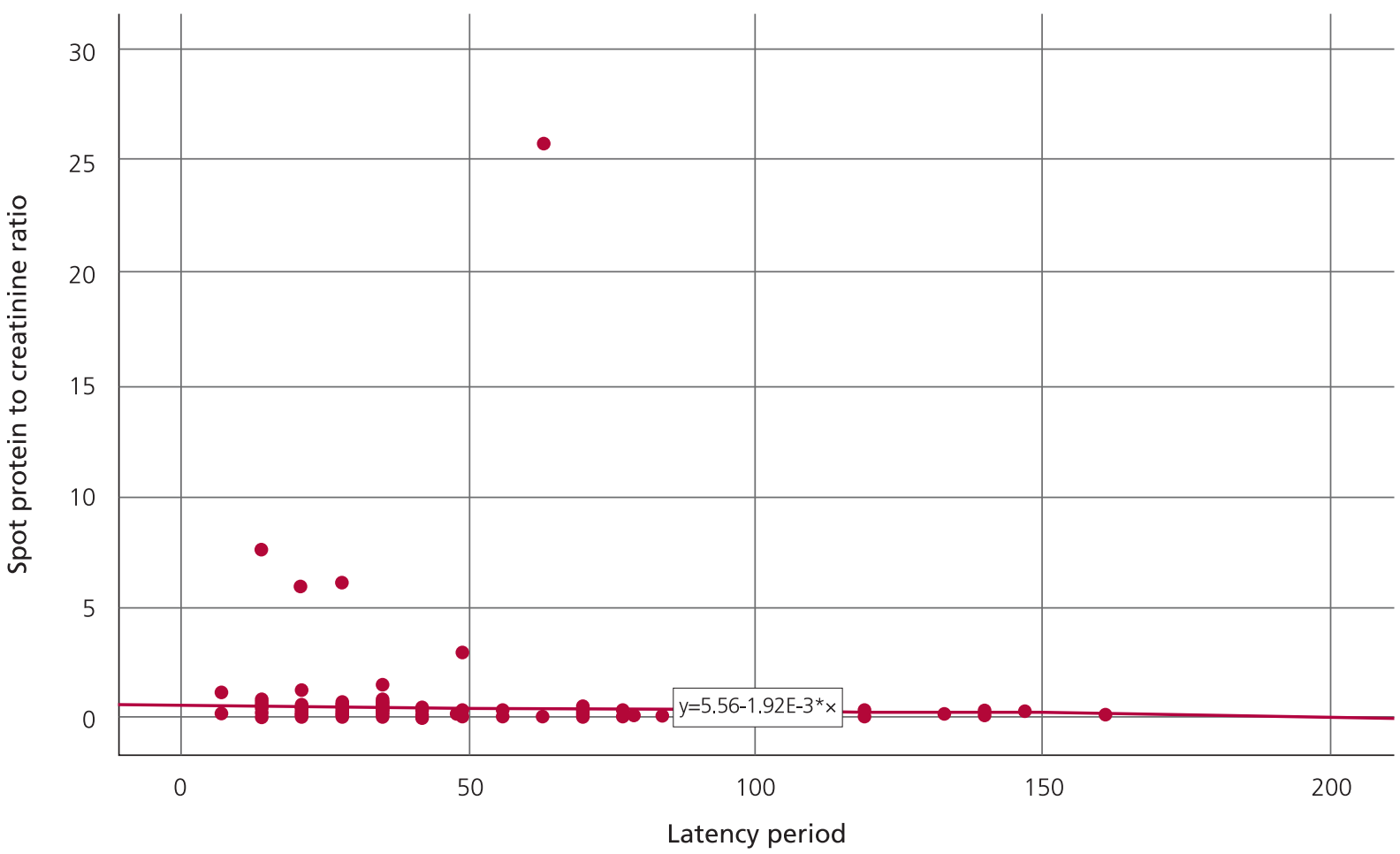

b

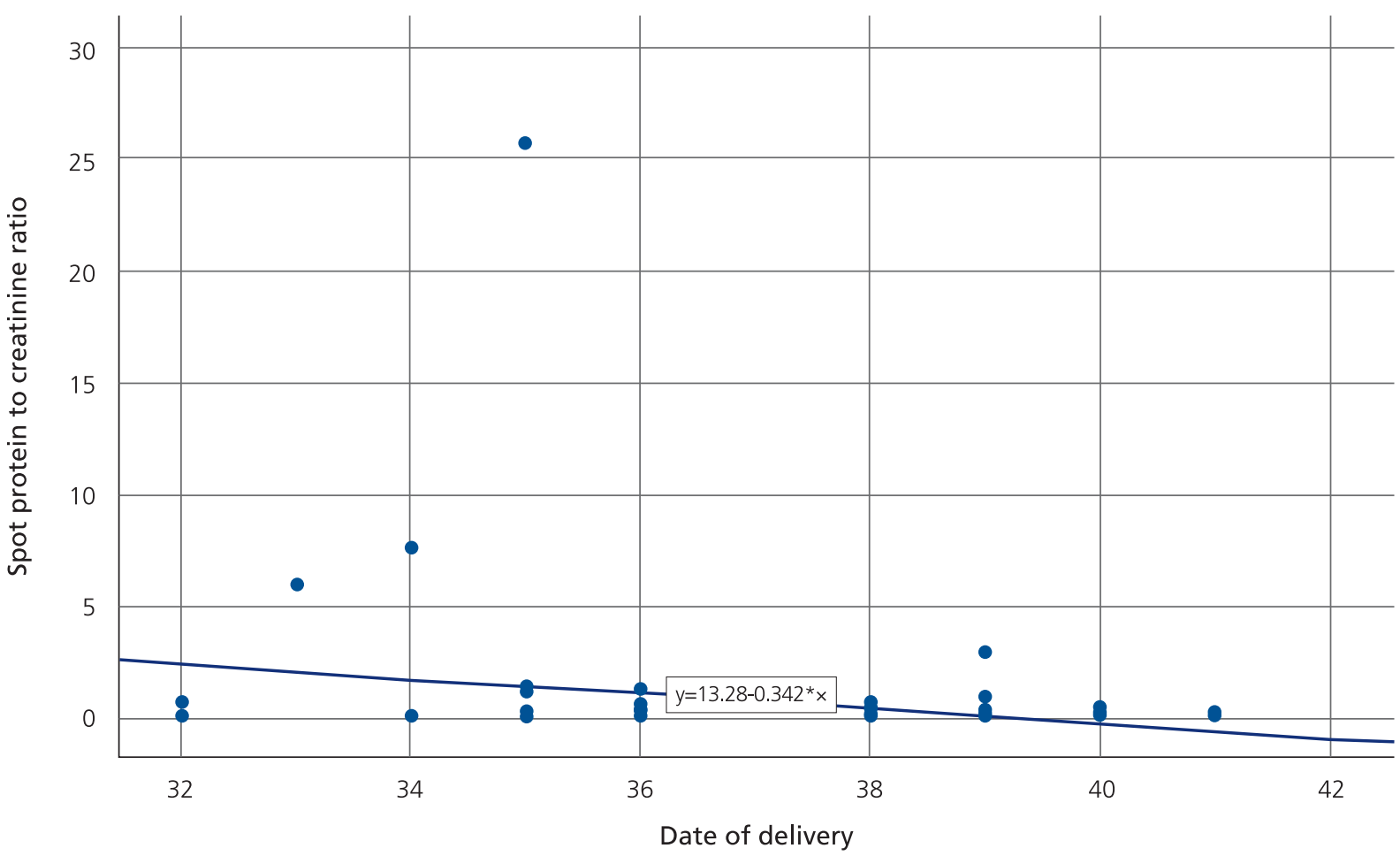

Fig. 2. (a) Correlation between spot urine P/C ratio and latency period. (b) Correlation between spot urine P/C ratio and date of delivery. 
Table 5. Comparison of 24-h urinary protein and spot urine P/C in the assessment of proteinuria.

\begin{tabular}{lcccc} 
& $\begin{array}{c}\text { 24-h proteinuria } \\
(\mathbf{3 0 0} \mathbf{~ m g})\end{array}$ & $\begin{array}{c}\mathbf{2 4 - h} \text { proteinuria } \\
(<\mathbf{3 0 0} \mathbf{~ m g})\end{array}$ & Total & $\mathbf{p}$-value \\
\hline Spot urine $P / C \geq 0.3$ & 60 & 10 & 100 & $<0.001$ \\
\hline Spot urine $P / C<0.3$ & 30 & 130 & 160 & 230 \\
\hline Total & 90 & 140 & 230 \\
\hline
\end{tabular}

infants born from proteinuric hypertensive pregnancy had a significantly higher rate of RDS, RDS with meconium aspiration, intubation, and NICU admission. Furthermore, both Apgar scores and the birth weight of these infants were significantly lower compared to infants born from non-proteinuric hypertensive pregnant women. Our findings revealed that proteinuria could be a good predictor of adverse neonatal outcomes and should be closely monitored as it could change the management of pregnancy with hypertension.

In our study population, the duration period from the hypertension diagnosis to the delivery in proteinuric pregnant women (proteinuria $\geq 300 \mathrm{mg} / 24-\mathrm{h}$ or $\mathrm{P} / \mathrm{C}$ ratio $\geq 0.3$ ) was significantly lower than those without proteinuria. Furthermore, gestational age at delivery of proteinuric pregnant women was significantly earlier than those without proteinuria. As far as we know, our study is one of the few studies that investigated the predictive value of proteinuria for the identification of delivery time. Ferrazzani et al. studied the effect of proteinuria on 444 hypertensive pregnant women and found a significant elevation in the incidence of early delivery among hypertensive pregnant women with proteinuria compared to those without proteinuria. ${ }^{[19]}$ However, they did not correlate the duration between the diagnosis of hypertension and delivery time. These

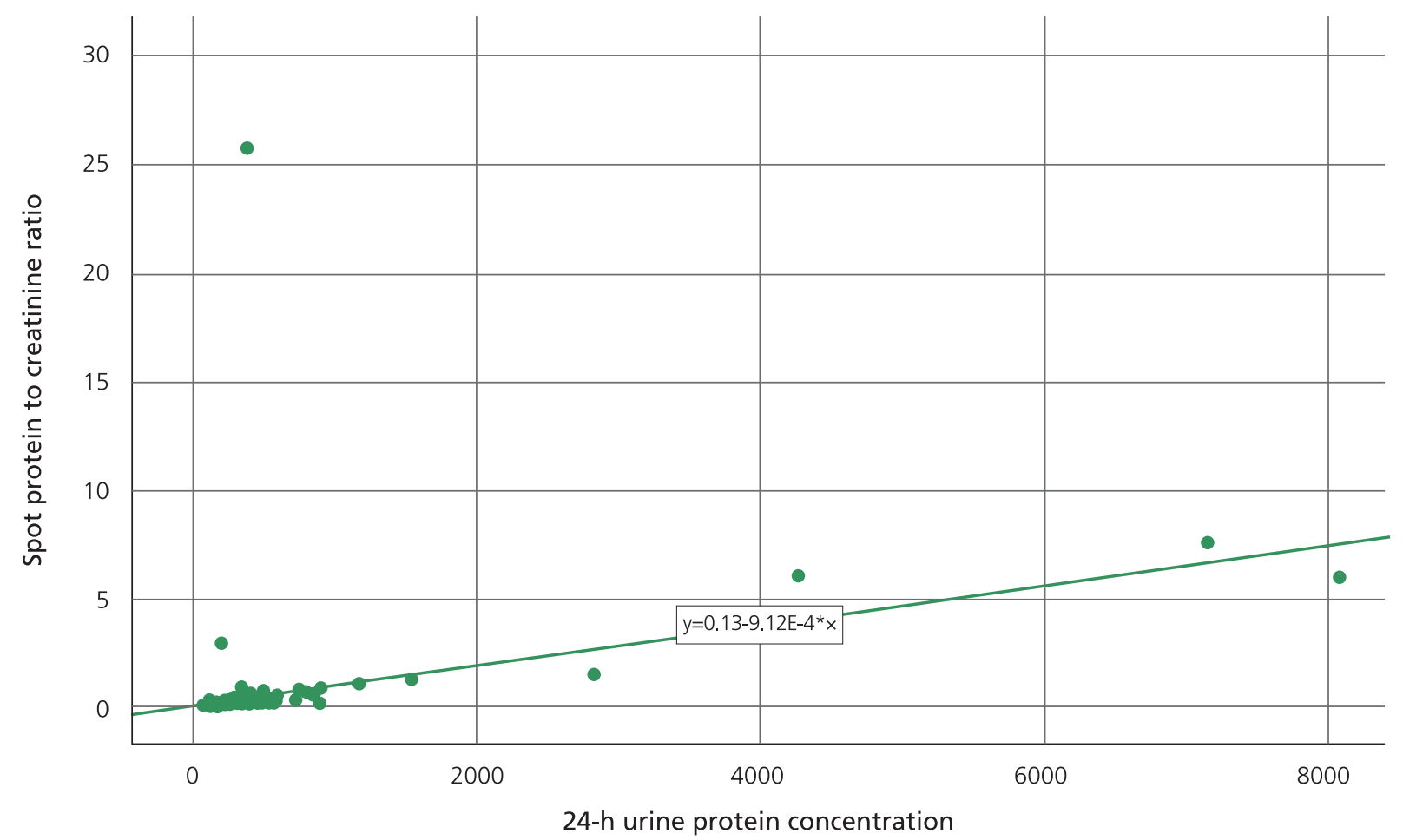

Fig. 3. Correlation between 24-h urinary protein concentration and spot urine P/C ratio. 
findings suggested that proteinuria independently from hypertension could be a risk factor for preterm delivery and could be used as one of the prognostic factors for the prediction of delivery time in pregnant women with hypertension. ${ }^{[20]}$

In 2013, the criteria for the preeclampsia diagnosis was revised by the American College of Obstetrics and Gynecology. Cases in which hypertension with low thrombocyte count, impaired renal functions, liver enzyme elevations, pulmonary edema, and central nervous system symptoms are classified as preeclampsia, even when proteinuria is not detected. ${ }^{[3]}$ Similarly, the International Society for the Study of Hypertension in Pregnancy reviewed its criteria for the diagnosis of preeclampsia in 2013 and decided that proteinuria is not necessary for the diagnosis. ${ }^{[2]}$ In the absence of proteinuria; the addition of end-organ dysfunction became an inclusion criterion of preeclampsia. This increased the frequency of preeclampsia all around the world because the rate of preeclampsia without proteinuria is about $10 \% .{ }^{[22]}$ However, we suggest giving specific importance to the amount of protein that is secreted to urine for the predictor of early delivery because many studies have shown that high proteinuria levels are associated with adverse perinatal outcomes. ${ }^{[23-25]}$

The limitations of our study are the relatively small sample size and the retrospective study design. Our study was retrospective so it brought the risk of missing data such as body mass index and additional illnesses of patients which may alter the prognosis. However, the strength of our study is all pregnant women were followed up in the same university hospital and there was no need to transfer them to any other institute. All pregnant women delivered their babies in our university hospital, and as there is an intensive care unit for newborns in our clinic, we also did not transfer the newborns to any other department. For these reasons, all antenatal and postnatal data were available in the medical charts and could be analyzed in detail.

\section{Conclusion}

In conclusion, our study demonstrated that a protein loss $\geq 300 \mathrm{mg}$ in $24-\mathrm{h}$ and a $\mathrm{P} / \mathrm{C}$ ratio in spot urine $\geq 0.3 \mathrm{in}$ hypertensive pregnant women is associated with adverse outcomes. Furthermore, we have identified that proteinuria $\geq 300 \mathrm{mg} /$ day and spot urine $\mathrm{P} / \mathrm{C}$ ratio $\geq 0.3$ in hypertensive pregnant women make them prone to early delivery risk. Therefore, the findings presented in this study can be used by clinicians to predict the adverse perinatal outcomes and expected delivery time of pregnant women with hypertension.

Funding: This work did not receive any specific grant from funding agencies in the public, commercial, or not-for-profit sectors.

Compliance with Ethical Standards: The authors stated that the standards regarding research and publication ethics, the Personal Data Protection Law and the copyright regulations applicable to intellectual and artistic works are complied with and there is no conflict of interest.

\section{References}

1. Leeman L, Fontaine P. Hypertensive disorders of pregnancy. Am Fam Physician 2008;78:93-100. [PubMed]

2. Fishel Bartal M, Lindheimer MD, Sibai BM. Proteinuria during pregnancy: definition, pathophysiology, methodology, and clinical significance. Am J Obstet Gynecol 2020;1:S00029378(20)30989-3. [PubMed] [CrossRef]

3. Hypertension in pregnancy. Report of the American College of Obstetricians and Gynecologists' Task Force on Hypertension in Pregnancy. Obstet Gynecol 2013;122:112231. [PubMed] [CrossRef]

4. Milne JE, Lindheimer MD, Davison JM. Glomerular heteroporous membrane modeling in third trimester and postpartum before and during amino acid infusion. Am J Physiol Renal Physiol 2002;282: F170-5. [PubMed] [CrossRef]

5. Higby K, Suiter CR, Phelps JY, Siler-Khodr T, Langer O. Normal values of urinary albumin and total protein excretion during pregnancy. Am J Obstet Gynecol 1994;171:984-9. [PubMed] [CrossRef]

6. Garg P, Rabelink T. Glomerular proteinuria: a complex interplay between unique players. Adv Chronic Kidney Dis 2011;18:233-42. [PubMed] [CrossRef]

7. Stefanska K, Zielinski M, Zamkowska D, Adamski P, JassemBobowicz J, Piekarska K, et al. Comparisons of dipstick test, urine protein-to-creatine ratio, and total protein measurement for the diagnosis of preeclampsia. Int J Environ Res Public Health 2020;17:4195. [PubMed] [CrossRef]

8. Kucukgoz Gulec U, Sucu M, Ozgunen FT, Buyukkurt S, Guzel AB, Paydas S. Spot urine protein-to-creatinine ratio to predict the magnitude of 24-hour total proteinuria in preeclampsia of varying severity. J Obstet Gynaecol Can 2017; 39:854-60. [PubMed] [CrossRef]

9. Waugh JJS, Clark TJ, Divakaran TG, Khan KS, Kilby MD. Accuracy of urinalysis dipstick techniques in predicting significant proteinuria in pregnancy. Obstet Gynecol 2004;103:76977. [PubMed] [CrossRef]

10. Cade TJ, Gilbert SA, Polyakov A, Hotchin A. The accuracy of spot urinary protein-to-creatinine ratio in confirming proteinuria in pre-eclampsia. Aust N Z J Obstet Gynaecol 2012;52: 179-82. [PubMed] [CrossRef] 
11. Pasternak Y, Lifshitz D, Shulman Y, Hiersch L, Rimon E, Kuperminc M, et al. Diagnostic accuracy of random urinary protein-to-creatinine ratio for proteinuria in patients with suspected pre-eclampsia. Arch Gynecol Obstet 2021;304:109-15. [PubMed] [CrossRef]

12. Payne B, Magee LA, Cote AM, Hutcheon JA, Li J, Kyle PM, et al. PIERS proteinuria: relationship with adverse maternal and perinatal outcome. J Obstet Gynaecol Can 2011;33:58897. [PubMed] [CrossRef]

13. Morikawa M, Mayama M, Saito Y, Nakagawa-Akabane K, Umazume T, Chiba K, et al. Severe proteinuria as a parameter of worse perinatal/neonatal outcomes in women with preeclampsia. Pregnancy Hypertens 2020;19:119-26. [PubMed] [CrossRef]

14. Nakanishi S, Aoki S, Nagashima A, Seki K. Incidence and pregnancy outcomes of superimposed preeclampsia with or without proteinuria among women with chronic hypertension. Pregnancy Hypertens 2017;7:39-43. [PubMed] [CrossRef]

15. Cruz MO, Gao W, Hibbard JU. OS015. What is the optimal time for delivery in women with gestationalhypertension? Pregnancy Hypertens 2012;2:182. [PubMed] [CrossRef]

16. Yuce T, Keskin M, Seval MM, Soylemez F. Effect of the timing of delivery on perinatal outcomes at gestational hypertension. Interv Med Appl Sci 2015;7:59-62. [PubMed] [CrossRef]

17. Gofton EN, Capewell V, Natale R, Gratton RJ. Obstetrical intervention rates and maternal and neonatal outcomes of women with gestational hypertension. Am J Obstet Gynecol 2001;185:798-803. [PubMed] [CrossRef]

18. Mikami Y, Takagi K, Itaya Y, Ono Y, Matsumura H, Takai Y, et al. Post-partum recovery course in patients with gestational hypertension and pre-eclampsia. J Obstet Gynaecol Res 2014; 40:919-25. [PubMed] [CrossRef]

19. Ferrazzani S, Caruso A, De Carolis S, Martino IV, Mancuso S. Proteinuria and outcome of 444 pregnancies complicated by hypertension. Am J Obstet Gynecol 1990;162:366-71. [PubMed] [CrossRef]

20. Tochio A, Obata S, Saigusa Y, Shindo R, Miyagi E, Aoki S. Does pre-eclampsia without proteinuria lead to different pregnancy outcomes than pre-eclampsia with proteinuria? J Obstet Gynaecol Res 2019;45:1576-83. [PubMed] [CrossRef]

21. Tranquilli AL, Brown MA, Zeeman GG, Dekker G, Sibai BM. The definition of severe and early-onset preeclampsia. Statements from the International Society for the Study of Hypertension in Pregnancy (ISSHP). Pregnancy Hypertens 2013;3:44-7. [PubMed] [CrossRef]

22. Thornton CE, Makris A, Ogle RF, Tooher JM, Hennessy A. Role of proteinuria in defining pre-eclampsia: clinical outcomes for women and babies. Clin Exp Pharmacol Physiol 2010;37:466-70. [PubMed] [CrossRef]

23. Mateus J, Newman R, Sibai BM, Li Q, Barton JR, Combs $\mathrm{CA}$, et al. Massive urinary protein excretion associated with greater neonatal risk in preeclampsia. AJP Rep 2017;7:e49e58. [PubMed] [CrossRef]

24. Chan P, Brown M, Simpson JM, Davis G. Proteinuria in pre-eclampsia: how much matters? BJOG 2005;112:280-5. [PubMed] [CrossRef]

25. Dong X, Gou W, Li C, Wu M, Han Z, Li X, et al. Proteinuria in preeclampsia: not essential to diagnosis but related to disease severity and fetal outcomes. Pregnancy Hypertens 2017;8:604. [PubMed] [CrossRef]

This work is licensed under the Creative Commons Attribution-NonCommercial-NoDerivs 4.0 Unported (CC BY-NC-ND4.0) License. To view a copy of this license, visit http://creativecommons.org/licenses/by-nc-nd/4.0/ or send a letter to Creative Commons, PO Box 1866, Mountain View, CA 94042, USA.

Publisher's Note: The content of this publication does not necessarily reflect the views or policies of the publisher, nor does any mention of trade names, commercial products, or organizations imply endorsement by the publisher. Scientific and legal responsibilities of published manuscript belong to their author(s). The publisher remains neutral with regard to jurisdictional claims in published maps and institutional affiliations. 